\title{
Charcot's paradox
}

\author{
O paradoxo de Charcot
}

Maren de Moraes e SILVA ${ }^{1}$, Alex Tiburtino MEIRA², Olivier WALUSINSKI ${ }^{3}$, Carlos Henrique Ferreira de CAMARGO4, Hélio Afonso Ghizoni TEIVE²

\begin{abstract}
Jean-Martin Charcot (1825-1893), considered the father of modern neurology, had a particular interest in pathology and learned to value anatomical findings. Among his main contributions is the use of the anatomo-clinical method in neurology. Although described as cold and impatient in his interpersonal relations, Charcot had a great affection for animals. He had two dogs in his home, which he called Carlo and Sigurd, and a little monkey, Rosalie. Despite his fascination with neuropathology and anatomo-clinical correlations, Charcot disapproved of studies using animal species other than humans, a seemingly paradoxical attitude. As a result, Charcot's human studies resulted in important advances in neurology as, prior to his research, anatomical observations of animals were extrapolated to humans, leading to conceptual errors.
\end{abstract}

Keywords: Neurology, history, Jean-Martin Charcot.

\section{RESUMO}

Jean-Martin Charcot (1825-1893), considerado o pai da neurologia moderna, teve sua formação direcionada para a patologia, aprendendo a valorizar achados anatômicos. Entre as principais contribuições de Charcot está o uso do método anatomoclínico aplicado à neurologia. Descrito como frio e impaciente em suas relações interpessoais, Charcot mostrava, no entanto, um grande afeto pelos animais. Ele tinha dois cachorros em sua residência, a quem chamou de Carlo e Sigurd, e uma pequena macaca, Rosalie. Apesar de sua fascinação com a neuropatologia e as correlações anatomoclínicas, Charcot foi contra estudos com outras espécies de animais que não humanos, o que pode parecer um paradoxo. Entretanto, seus estudos trouxeram avanços importantes para a Neurologia, uma vez que, antes de suas descobertas, as observações anatômicas dos animais eram extrapoladas para os humanos, levando a erros conceituais.

Palavras-chave: Neurologia, história, Jean-Martin Charcot.

Jean-Martin Charcot (1825-1893), considered the father of modern neurology, had a particular interest in pathology and learned to value anatomical findings ${ }^{1,2,3}$. Throughout his career, he developed new methods for classifying neurological diseases based on his observations and on anatomo-clinical correlations ${ }^{3,4}$. Many of these methods and the initial concepts on which they were based continue to be used more than a hundred years after Charcot's death ${ }^{5,6}$. As his student, Joseph Babinski noted, "to take away from neurology all the discoveries made by Charcot would be to render it unrecognizable"5. The main traits that defined the complex personality of the French neurologist included authoritarianism, austerity, shyness, sarcasm and skepticism and, curiously, a great affection for animals, refusing to allow studies with vivisection and cruel treatment of animals ${ }^{1,7,8}$.

\section{A FASCINATION WITH THE ANATOMO-CLINICAL METHOD}

Among Charcot's main contributions is the use of the anatomo-clinical method in neurology $y^{1,2,3}$. This method, created by the Italian pathologist, Giovanni Battista Morgagni (1682-1771), and improved by René Laennec (1781-1826), a French physician who invented the stethoscope ${ }^{5}$, involved correlating patients' longitudinal clinical findings with

${ }^{1}$ Hospital da Cruz Vermelha Brasileira Filial do Paraná, Serviço de Neurologia, Curitiba PR, Brasil;

${ }^{2}$ Universidade Federal do Paraná, Hospital de Clínicas, Departamento de Clínica Médica, Serviço de Neurologia, Curitiba PR, Brasil;

${ }^{3}$ General Practice, Brou, France;

«Universidade Estadual de Ponta Grossa, Hospital Universitário, Serviço de Neurologia, Ponta Grossa PR, Brasil.

Maren de Moraes e Silva (iD) https://orcid.org/0000-0001-7169-102X;AlexTiburtino Meira (iD https://orcid.org/0000-0002-6685-7491;Olivier Walusinski (D https://orcid.org/0000-0001-6927-7946; Carlos Henrique Ferreira de Camargo iD https://orcid.org/0000-0002-3533-0347; Hélio Afonso Ghizoni Teive iD https://orcid.org/0000-0003-2305-1073

Correspondence: Hélio A. G. Teive; Rua General Carneiro 1103/102 - Centro; 80060-150 Curitiba PR, Brasil; E-mail: hagteive@mps.com.br

Conflict of interest: There is no conflict of interest to declare.

Received 10 September 2018; Received in final form 30 October 2018; Accepted 13 November 2018. 
autopsy analyses using microscopy and photography ${ }^{3}$. Charcot worked at La Salpêtrière Hospital, which, at the time, was merely an asylum transformed into a hospital that housed many patients with neurological diseases or, as he referred to it, a musée pathologique vivant (a "living museum of pathology"), providing a wealth of material for his studies $^{9,10}$. Through his own efforts, he turned the center into a reference for neurological cases in the $19^{\text {th }}$ century, creating "the Mecca of clinical neurology"1,5. As the bodies of many patients who died at the hospital were not claimed by relatives, Charcot was frequently able to carry out studies and autopsies, giving him the opportunity to describe and categorize many neurological morbidities ${ }^{5}$. This was particularly important to him as he believed that "a physician is only as good a clinician as he is a pathologist". Various neurological conditions and pathologies still bear Charcot's name, reflecting his importance in the field of neurology: amyotrophic lateral sclerosis (Charcot's disease), hereditary sensory-motor neuropathy (Charcot-Marie-Tooth disease), tabes dorsalis arthropathy (Charcot's arthropathy) and primary intracerebral hemorrhage (microaneurysms of Charcot-Bouchard). Many other, no less important, conditions were also described by Charcot: multiple sclerosis, Parkinson's disease and Tourette Syndrome ${ }^{1,2,3,5,6,7,7,8,9,11}$. In addition to being able to correlate clinical and anatomical findings, Charcot made important contributions to neuroanatomy, since prior knowledge in this area was based on the findings of animal dissections, which did not always correspond to the findings in humans ${ }^{5}$.

\section{CHARCOT'S RELATIONSHIP WITH ANIMALS}

Although described as cold, reserved, austere and impatient in his interpersonal relations ${ }^{1-3,5,7,8}$, Charcot had a great affection for animals. According to his biographies, including the classic Charcot Intime by Guinon ${ }^{12}$, Charcot had two dogs in his home, at 217 Boulevard Saint-German, Paris, that he called Carlo and Sigurd (Figure 1), as well as a small female monkey, called Rosalie (Figure 2A and 2B), that was his favorite. Rosalie would keep him company even during his meals, and Charcot took care of her food and laughed at her pranks. The monkey was a gift from Dom Pedro II, Emperor of Brazil, and belonged to the species Cebus apella, which is common in Brazil and is known for being smart, friendly and funny ${ }^{1,12,13}$. Goetz et al. ${ }^{1}$, in their very famous book about Charcot, Charcot: Constructing Neurology, mention a well-known tale involving Rosalie, as recalled by Charcot's granddaughter. During a dinner at Charcot's house, attended by numerous international authorities, the little monkey climbed onto the dining room table, which was elegantly decorated for the occasion, and completely dismantled the centerpiece. However, rather than upsetting the guests, the incident helped to set them at ease ${ }^{1,13,14}$.

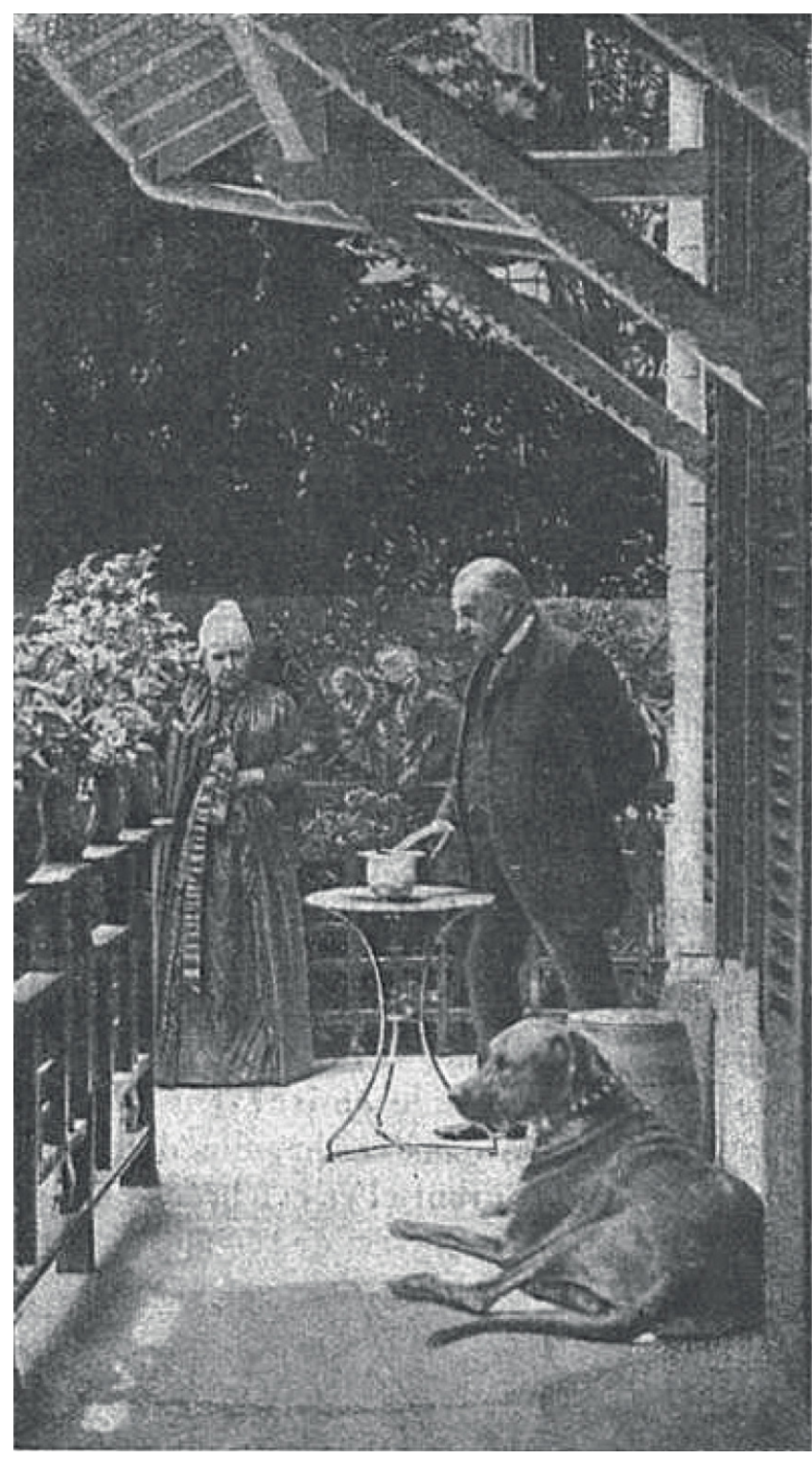

(Extracted from Souques A. Charcot Intime. La presse medicale 1925; 42 693-700)

Figure 1. Charcot on the terrace of his house in Neuilly sur Seine, with Augustine Charcot, his wife, and Sigurd, one of his dogs.

\section{CHARCOT'S PERSONAL ETHICS}

Charcot's love of animals would appear to have gone beyond mere professional concern. Previous reports describe that the physician was against hunting and bullfighting, in addition to not allowing vivisection or experiments involving animals at La Salpêtrière Hospital - most of his neuroanatomical and neuropathological studies were based on human autopsies ${ }^{1,13,14,15,16}$. Even in his office, there was a sign with the words: "You will find no dog laboratory here"16. This attitude contrasted with his great interest in autopsy studies in patients who died at the hospital, which led to the discovery of several neurological diseases ${ }^{1,2,3,4,5,6}$. The use of animals in scientific research and for drug testing is currently the subject of considerable controversy. Kirk ${ }^{17}$ recently published 


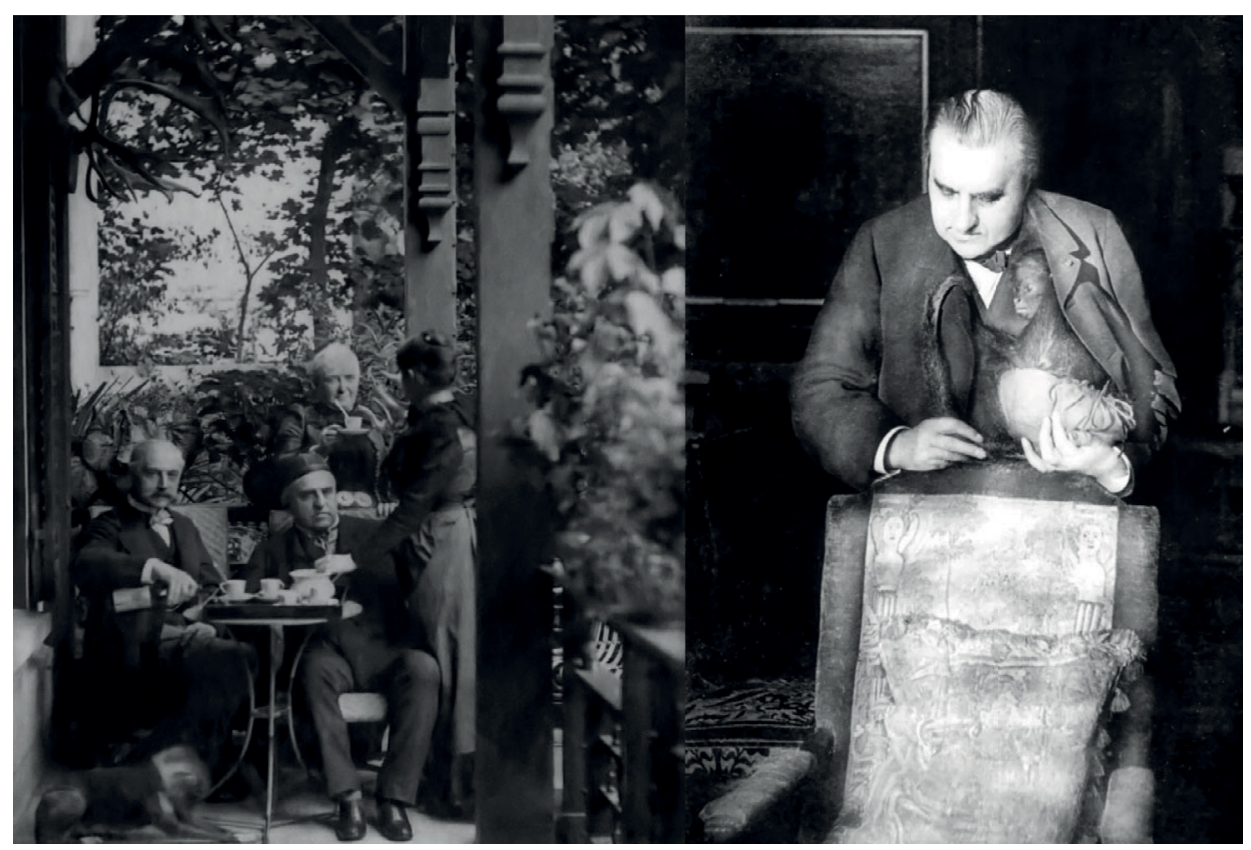

Figure 2. Charcot and Rosalie, his monkey. A: René Vallery-Radot seated (1853-1933), son-in-law of Louis Pasteur (1822-1895), J.M. Charcot and his pet-monkey at their feet. Augustine Charcot, his wife and, probably, Jeanne Charcot their daughter. On the terrace of Charcot's house in Neuilly sur Seine. (Allart-Vallin-Charcot family private archives, with kind permission). B: Charcot holding his pet monkey sheltered inside his coat. (Allart-Vallin-Charcot family private archives, with kind permission).

an article on this issue entitled Recovering the principles of humane experimental technique: The 3Rs and the human essence of animal research. The author emphasizes the importance of the seminal book published by Russel and Burch ${ }^{18}$ in 1959, The Principles of Humane Experimental Technique, and discusses the 3Rs, or the replacement, reduction and refinement of animal research, which govern the use of animals in scientific procedures. Neurological research using nonhuman primates is also currently a subject of debate ${ }^{19}$. Another important related issue is the use and postmortem removal of human tissue for research, which has created many legal and ethical dilemmas. This issue was recently discussed by Klioueva et al. ${ }^{20}$ in a paper on the development of the code of conduct for brain banking and its foundations. These papers enable Charcot's controversial and paradoxical position to be discussed in the context of, and compared with, current views on these issues.

\section{CONCLUSION}

Despite his fascination with neuropathology and anatomo-clinical correlations, Charcot disapproved of studies with animal species other than humans. Nevertheless, Charcot's studies resulted in important advances in neurology, as prior to his research, anatomical observations of animals were extrapolated to humans, leading to conceptual errors. Despite his refusal to allow animal experiments or vivisection, Charcot became famous around the world for his descriptions of many pathologies.

\section{References}

1. Goetz CG, Bonduelle M, Gelfand T. Charcot: constructing neurology. New York: Oxford University Press; 1995. p. 268-304.

2. Guillain GJ. Charcot: his life-his work. New York: Paul B. Heber; 1959.

3. Goetz CG. Jean-Martin Charcot (1825-1893). J Neurol. 2005;252(3):374-5. https://doi.org/10.1007/s00415-005-0776-1

4. Goetz CG. Chapter 15: Jean-Martin Charcot and the anatomo-clinical method of neurology. Handb Clin Neurol. 2010;95:203-12. https://doi.org/10.1016/S0072-9752(08)02115-5

5. Tan SY, Shigaki D. Jean-Martin Charcot (1825-1893): pathologist who shaped modern neurology. Singapore Med J. 2007 May;48(5):383-4

6. Bonduelle M. [Charcot, anatomo-pathologist]. Arch Anat Cytol Pathol. 1994;42(3-4):171-80.
7. Teive HA, Germiniani FM, Munhoz RP. Charcot's irony and sarcasm. Arq Neuropsiquiatr. 2017 Jun;75(6):402-4. https://doi.org/10.1590/0004-282×20170062

8. Teive HA, Munhoz RP, Silva GG. Charcot's skepticism. Arq Neuropsiquiatr. 2012 Nov;70(11):897-9. https://doi.org/10.1590/S0004-282X2012001100014

9. Jay V. The legacy of Jean-Martin Charcot. Arch Pathol Lab Med. 2000 Jan;124(1):10-1.

10. Thorburn AL. Jean-Martin Charcot, 1825-1893: an appreciation. Br J Vener Dis. 1967 Jun;43(2):77-80

11. Teive HA, Germiniani FM, Munhoz RP, Paola L. 126 hysterical years - the contribution of Charcot. Arq Neuropsiquiatr. 2014 Aug;72(8):636-9. https://doi.org/10.1590/0004-282X20140068 
12. Guinon G. Charcot Intime. Paris Med (Paris). 1925 May;511-6.

13. Teive HA, Arruda WO, Werneck LC. Rosalie: the Brazilian female monkey of Charcot. Arq Neuropsiquiatr. 2005 Sep;63(3A):707-8. https://doi.org/10.1590/S0004-282X2005000400031

14. Teive HA, Almeida SM, Arruda WO, Sá DS, Werneck LC. Charcot and Brazil. Arq Neuropsiquiatr. 2001 Jun;59 2-A:295-9. https://doi.org/10.1590/S0004-282X2001000200032

15. Hierons R. Charcot and his visits to Britain. BMJ. 1993 Dec;307(6919):1589-91. https://doi.org/10.1136/bmj.307.6919.1589

16. Finger S. Minds behind the brain: a history of the pioneers and their discoveries. New York: Oxford University Press; 2000.

17. Kirk RG. Recovering the principles of humane experimental technique: The 3Rs and the human essence of animal research. Sci Technol Human Values. 2018 Jul;43(4):622-48. https://doi.org/10.1177/0162243917726579

18. Russel WM, Burch R. The principles of humane experimental technique. London: Methuen; 1959.

19. Arnason G, Clausen J. On balance: weighing harms and benefits in fundamental neurological research using nonhuman primates. Med Health Care Philos. 2016 Jun;19(2):229-37. https://doi.org/10.1007/s11019-015-9663-4

20. Klioueva NM, Rademaker MC, Dexter DT, Al-Sarraj S, Seilhean D, Streichenberger N, et al. BrainNet Europe's code of conduct for brain banking. J Neural Transm (Vienna). 2015 Jul;122(7):937-40. https://doi.org/10.1007/s00702-014-1353-5 